\title{
Structural Analyses and Assessment of Historical Kamanlı Mosque in Izmir, Turkey
}

\author{
Egemen Teomete ${ }^{1}$ and Engin Aktaş $^{2}$
}

\begin{abstract}
Historical structures are one of the most precious pieces of cultural accumulation. In this study, an interdisciplinary work was conducted to assess the structural condition of a historical masonry structure, Urla Kamanlı Mosque in İzmir, Turkey. The structure is a member of group of structures, Yahşi Bey Complex, which includes a Turkish bath, a tomb, two fountains, and a primary school. The structure dates back to early 14th century to mid-15th century. History investigation, measurement survey, long-term settlement, and moisture observations were conducted. Nondestructive and destructive material tests were performed on stone, brick, and mortar. 3D finite-element model of the structure was used to investigate the critical locations of the structure under its self-weight, seismic load, and settlement load. Linear elastic and nonlinear settlement analyses were conducted to investigate the reason for massive cracks challenging the structural integrity.
\end{abstract}

DOI: $10.1061 /(\mathrm{ASCE}) \mathrm{CF} .1943-5509.0000111$

CE Database subject headings: History; Masonry; Nondestructive tests; Settlement; Finite element method; Structural analysis; Turkey.

Author keywords: Historical masonry; Nondestructive tests; Destructive tests; Settlement; Finite-element analyses.

\section{Introduction}

Over time, historical masonry structures suffer from damage due to material degradations, differential settlements, seismic actions, and other environmental effects. These damages result in structural instabilities that can cause the structure to fail. In the case of historical structures, preservation is often the goal. The structure needs to be assessed in such a way that can provide insight into the primary failure mechanisms and provide a path for the structure to be rehabilitated. In order to make such an assessment, measurement survey, material tests, soil survey, long-term observations, and structural tests and analyses should be applied (Ersoy 1990).

Extensive work has been published in the literature for structural assessment procedures. Destructive and nondestructive tests are conducted in order to characterize the materials of the structure (Binda et al. 2000). By using the data gathered from the tests, numerical models such as finite-element model of the structure were developed and structural analyses were conducted (Koçak 1999). In order to calibrate the models, system identification techniques such as ambient vibration tests were performed (Çakmak et al. 1993).

Schueremans et al. (2007) worked on assessment and rehabilitation of consolidation problems of the Church of Saint James at Leuven. Paret et al. (2008) studied seismic analyses and strength-

\footnotetext{
${ }^{1}$ Research Assistant, Dept. of Civil Engineering, Izmir Institute of Technology, Urla, Izmir 35430, Turkey.

${ }^{2}$ Assistant Professor, Dept. of Civil Engineering, Izmir Institute of Technology, Urla, Izmir 35430, Turkey (corresponding author).

Note. This manuscript was submitted on July 24, 2009; approved on December 23, 2009; published online on January 9, 2010. Discussion period open until January 1, 2011; separate discussions must be submitted for individual papers. This paper is part of the Journal of Performance of Constructed Facilities, Vol. 24, No. 4, August 1, 2010. (CASCE, ISSN 0887-3828/2010/4-353-364/\$25.00.
}

ening of a masonry structure in San Francisco. Mistler et al. (2006) worked on seismic analyses of Aachen Cathedral using finite-element method.

Understanding the behavior of the masonry structures has long been a goal of the structural engineering community. Several practical structural analyses techniques such as force polygon and the chain rule have been used to determine the reasons for structural damage in various masonry structures (Heyman 1982). The development of high speed computing has furthered the analysis capabilities allowing for approaches like generalized matrix formulations (Roca 2001) and finite-element methods. Andreu et al. (2007) applied a new cable element in finite-element analysis and limit analyses to determine the safety of masonry structures.

There are two approaches in modeling masonry: micromodeling in which mortar joints and units are modeled separately, and macromodeling in which a constitutive relation for overall constituents of masonry is defined (Lourenço 1996). DruckerPrager's yield criterion was adopted for structural analyses of church steeples (Sofronie et al. 2001) and for analyses of St. Bergius and Bacchus Church (Küçük Ayasofya Mosque) (Koçak 1999). Finite-element analyses by using discontinuous elements and discrete elements were conducted in order to model a masonry test and consistent results were obtained (Giordano et al. 2002). An interface model for mortar derived from concepts of rock mechanics and tribology was used to model masonry by microapproach in which mortar and units are modeled separately (Giambanco et al. 2001). An orthotropic damage model was specifically developed for the analysis of masonry under in-plane loading (Berto et al. 2002).

In micromodeling, by making the assumption that all inelastic response occur in the interface elements, a robust model can be developed, capable of following the complete load path of a structure until total degradation of stiffness is achieved. Lourenço (1996) described such a model which includes a tension cutoff for Mode I failure, a Coulomb friction envelope for Mode II failure, and a cap mode for compressive failure. In macromodeling of the 


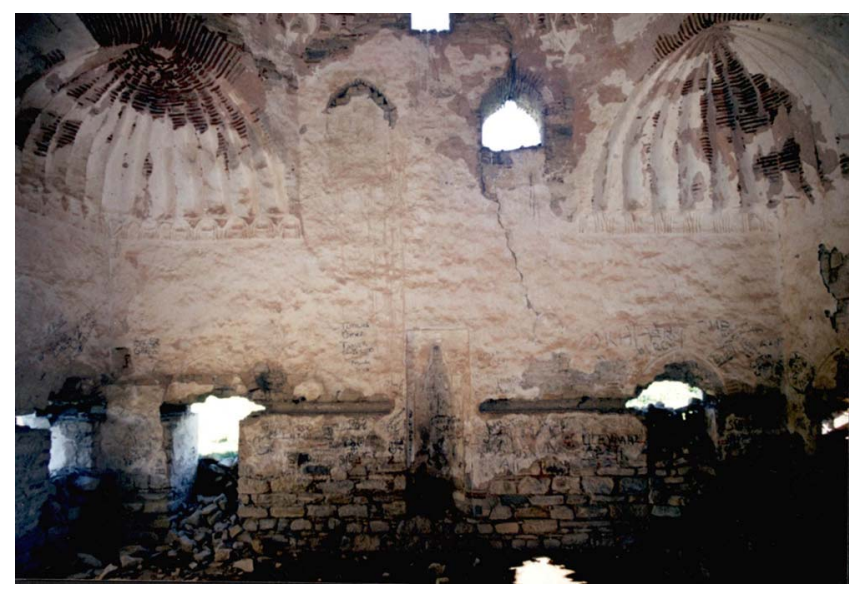

Fig. 1. East section view of the structure

orthotropic behavior of masonry structures, a Hill type yield criterion for compression and a Rankine type yield criterion for tension were proposed by Lourenço (1996).

Herein a comprehensive study on the assessment of a historical masonry structure is presented. The Urla Kamanli Mosque in Urla, Izmir, Turkey is a member of a group of structures named Yahşi Bey Complex, which contains a Turkish bath, a tomb, two fountains, and a primary school. Although there is not any written document kept about the construction date and constructors, by using comparative methods of architectural elements in light of art history it is concluded that the structures date back to an era of early 14th century to mid-15th century (Erim 1995).

Historical investigation, measurement survey, nondestructive and destructive tests, and long-term observations were conducted for the Kamanli Mosque in İzmir, Turkey. On the basis of the data gathered, a three-dimensional (3D) finite-element model of the structure was developed. In order to determine the structural behavior and the causes of existing damage of the structure, linear elastic analyses for dead load, response spectrum, and settlement loadings and nonlinear settlement analyses were conducted.

\section{Description of the Structure}

The structure has a square plan of $10 \mathrm{~m} \times 10 \mathrm{~m}$ with a wall thickness of $110 \mathrm{~cm}$ and the height of the structure is $12.66 \mathrm{~m}$. The walls of the structure are stone masonry with limestone and thick mortar joints. The window arches and the dome are brick masonry with thick mortar joints. The transition from walls to dome on the corners is achieved by use of squinches which are also brick masonry as seen in Fig. 1.

The structure had not been used for a long time and was open to all environmental effects since the windows and the door of the structure do not exist. Inside the structure, especially in the first 1 $\mathrm{m}$ above the ground level, there is an extensive material degradation because of moisture. The wooden lintels which should surround the walls (along the inner and outer perimeters) at two levels do not exist, as can be seen in Fig. 1. Due to that, the cross sections of the walls at the wooden lintel levels decrease considerably which weakens the structure.

On the east and west walls, extensive cracks follow the pathway of the windows and joins at the key stone of the dome (Fig. 1). In this study, the causes of these cracks have been investigated using 3D finite-element model of the structure.

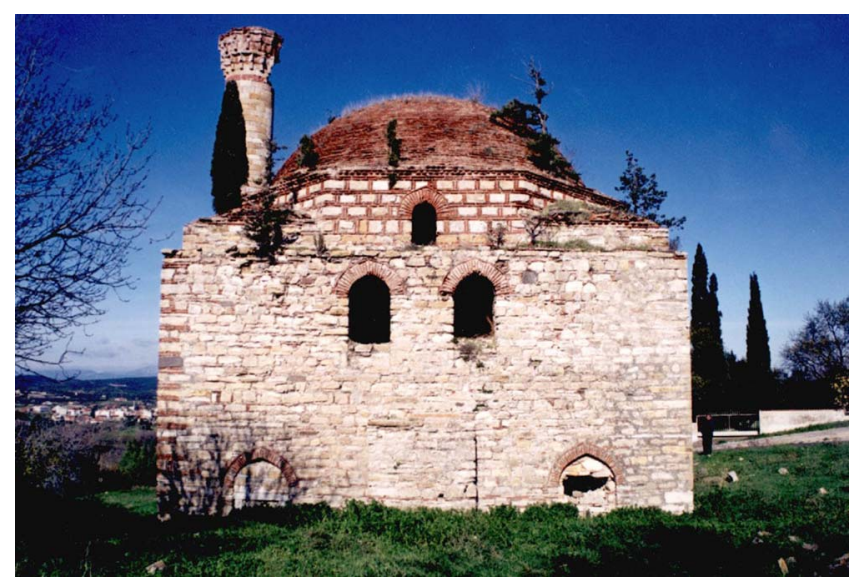

Fig. 2. South elevation view of the structure

The part of the minaret above the balcony collapsed during a storm according to the locals (Fig. 2). Plant formations on the structure challenge the structure's integrity as well; a tree growing on the wall near the drum has a height of $3 \mathrm{~m}$, which is a clear sign that the structure has not been used for a long time. The drum and the west wall of the structure have a more qualified weave than the other walls (Fig. 2). According to Erim (1995), because of the primary school on the west side of the mosque, that part is a social zone, therefore has a more qualified weave than the other walls.

In order to investigate the local soil conditions, two geological reports which belong to neighboring parcels were obtained from Urla Municipality, Turkey. The region is composed of Miocene old limestone, clay, marl, and volcanic ash. Limestone is dominant. The top $30 \mathrm{~cm}$ to $1.5 \mathrm{~m}$ is composed of organic soil (Alkan 1994). The region is under the effect of Alpine tectonics and in the first-order seismic zone (Ispir 2000).

The structure is in a seismically active region, and survived five earthquakes magnitudes of $\mathrm{Ms}=5.6,5.7,5.8,5.9$, and 5.9 with epicenters close to the structure during this study. When the age of the structure is considered, it is obvious that it had survived many earthquakes. The five earthquakes, which occurred during this study, did not affect the structural condition by means of existing crack propagation or new crack formation.

\section{Long-Term Settlement and Relative Moisture Measurements}

In order to understand the behavior of the structure, settlement and relative moisture long-term observations were conducted.

\section{Long-Term Settlement Measurements}

The massive cracks on the east and west walls might be due to differential settlements. Settlement measurements were conducted by attaching studs on the corners of the structure. Studs 1, 2, and 3 are on the east wall corners; Studs 4 and 5 are on the north wall corners; 6 and 7 are on the west wall corners; Studs 8 and 9 are on the south wall corners. The heights of the studs were measured with respect to a local observation point using geodetics techniques with a 3-month period for 1 year.

There are decreases in heights, especially for the Studs 4 and 5 at the north elevation, which means that there is a settlement toward north direction, as seen in Fig. 3. 


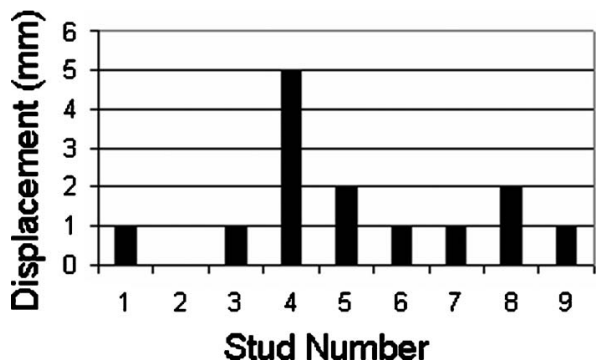

Fig. 3. Settlement measurements

\section{Relative Moisture Measurements}

There is a vast amount of material degradation that challenges the structure. Especially, at the first $1 \mathrm{~m}$ from the ground level, in the structure, material deterioration can be observed visually. These regions are thought to be vulnerable in case of a seismic loading where high amount of the shear forces will act on.

It has been observed that since the structure does not have windows, door, and insulation for water, the moisture level in the structure is high. When it rains, the water passes through the dome and seeps into the structure. The evaporation rate is low and the moisture level is always higher in the structure than outside the structure.

The relative moisture of the stones and mortars at each section and at bottom ( $1 \mathrm{~m}$ from ground) and top ( $2 \mathrm{~m}$ from ground) have been observed monthly. A nondestructive moisture meter of

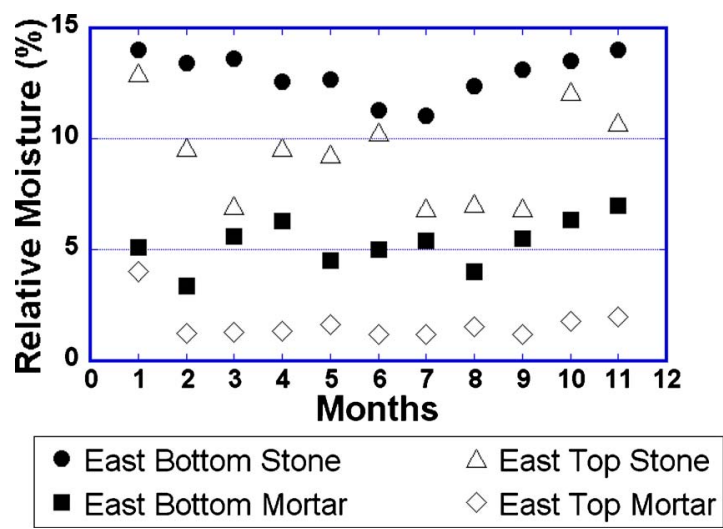

Fig. 4. Relative moisture measurements

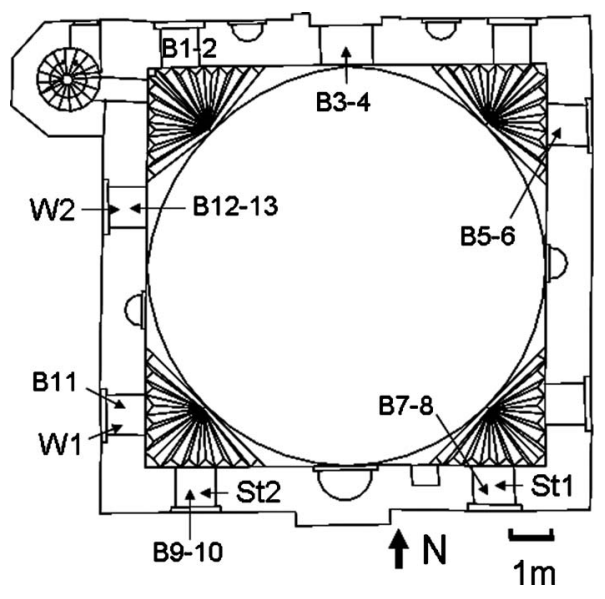

Fig. 5. Locations of stones (St1-2, W1-2) and bricks (B1-13) obtained from the structure

James Instruments Inc. which uses electromagnetic methods for determining the relative moisture to a depth of 1 in. $(25 \mathrm{~mm})$ was used. In Fig. 4, the relative moisture readings of the east section are given. The moisture at the bottom for stone is higher than the moisture of the stone at the top, and the same relation is valid for the mortar. At lower levels, moisture oriented degradation of materials is observed.

\section{Material Tests}

In order to characterize the materials of the structure, nondestructive and destructive tests were applied on stone, brick, and mortar samples obtained from the structure. Two stones from the south wall, two stones from the west wall, and 13 bricks were collected from locations in Fig. 5. The stone samples were obtained from bases of the first level window openings, and bricks were obtained from arches of the first level window openings. The tests' results on mortar were obtained from Architectural Restoration Department of Izmir Institute of Technology.

Cylinder core samples having diameters of $D=54 \mathrm{~mm}$ were drilled from stones. The heads of the samples were cut off and polished by iron dust to have smooth and parallel surfaces.

The ultrasonic pulse velocity test was applied by using CNS Farnell Electronic's Pundit type equipment on stone core and brick samples. The digital unit gives the time needed for the ul-

Table 1. Material Test Results

\begin{tabular}{|c|c|c|c|c|c|c|c|}
\hline Location & $\begin{array}{c}\text { Schmidt } \\
\text { hammer } \\
(R)\end{array}$ & $\begin{array}{l}\text { Pulse } \\
\text { velocity } \\
(\mathrm{m} / \mathrm{s})\end{array}$ & $\begin{array}{l}\text { Density } \\
\left(\mathrm{kg} / \mathrm{m}^{3}\right)\end{array}$ & $\begin{array}{c}\text { Compressive } \\
\text { strength } \\
(\mathrm{MPa})\end{array}$ & $\begin{array}{l}\text { Tensile } \\
\text { strength } \\
(\mathrm{MPa})\end{array}$ & $\begin{array}{l}\text { Elasticity } \\
\text { modulus } \\
(\mathrm{MPa})\end{array}$ & $\begin{array}{c}\text { Porosity } \\
\text { (\%) }\end{array}$ \\
\hline Stone south 1 & 30.8 & 3,291 & 2,498 & 64.17 & 5.72 & 9,221 & 15 \\
\hline Stone south 2 & 31.7 & 3,456 & 2,531 & 65.44 & 7.41 & 9,247 & 11 \\
\hline Stone west 1 & 39.7 & 5,187 & 2,596 & 127.8 & 8.49 & 30,895 & 2 \\
\hline Stone west 2 & 38 & 5,536 & 2,515 & 105.9 & 9.88 & 27,245 & 0.7 \\
\hline Brick & NA & 1,398 & 1,800 & 11.68 & 1.867 & 866 & 29 \\
\hline Mortar $S^{a}$ & NA & NA & 1,690 & 4.19 & 0.73 & 110 & 32 \\
\hline Mortar $\mathrm{B}^{\mathrm{b}}$ & NA & NA & 1,400 & 8.75 & 0.95 & 264 & 43 \\
\hline
\end{tabular}

Note: NA=not applicable.

${ }^{\mathrm{a}}$ Stone masonry.

${ }^{\mathrm{b}}$ Brick masonry. 


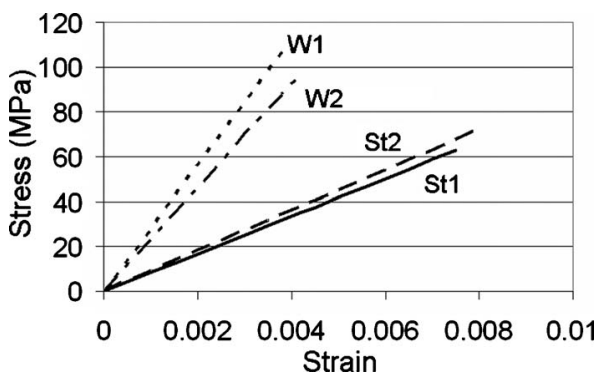

Fig. 6. Stress-strain graph obtained from uniaxial compression test for stone samples

trasonic pulse waves to pass the sample. From the distance between the probes, the velocity of the wave was calculated and is presented in Table 1. Brick cylinder core samples of diameter $D=25.6 \mathrm{~mm}$ were drilled out after the ultrasonic pulse velocity test.

Schmidt rebound hardness test was applied to stone cylinder core samples according to International Society for Rock Mechanics (ISRM) (1981). Type L Schmidt hammer having an impact energy of $0.74 \mathrm{Nm}$ was used. The sample was held by a steel cradle having a cylindrical slot of the same radius of the core. The test was applied to 37 core samples and averages for each stone are presented at Table 1 .

The density and porosity of the stone, brick, and mortar samples were determined according to RILEM Commission 25 PEM (1980). The averages of density and porosity of the samples are presented in Table 1. The relative moisture level of the stone core samples just before the tests were found to be in the range of $5-14 \%$ which is also the range for in situ measurements.

Uniaxial compression test was applied to stone, brick, and mortar core samples according to International Society for Rock Mechanics (ISRM) (1981). The test was conducted using a mechanical testing machine which can read the stroke from the loading head. The modulus of elasticity was determined by using the stress-strain curves obtained from uniaxial compression tests. The tangent modulus at $50 \%$ of compressive strength is determined to be the modulus of elasticity. The averages of the uniaxial compressive strength and modulus of elasticity of the stone, brick, and mortar samples are presented in Table 1. The stress-strain curves obtained for stone and brick samples are presented in Figs. 6 and 7. Indirect tension test was applied to the stone, brick, and mortar core samples according to International Society for Rock Mechanics (ISRM) (1981). The average tensile strengths of samples are presented in Table 1. The chemical composition of the stones was determined to be $\mathrm{CaCO}_{3}$ by use of Philips X-Pert X-Ray

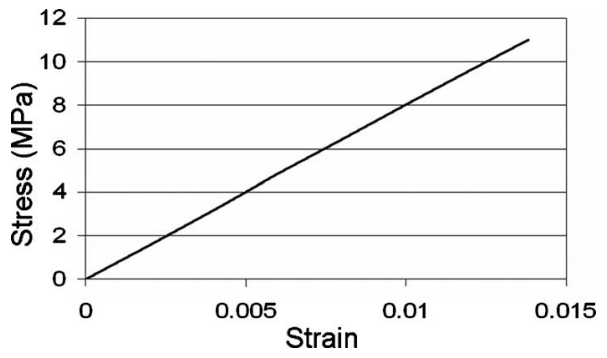

Fig. 7. Stress-strain graph obtained from uniaxial compression test for brick sample

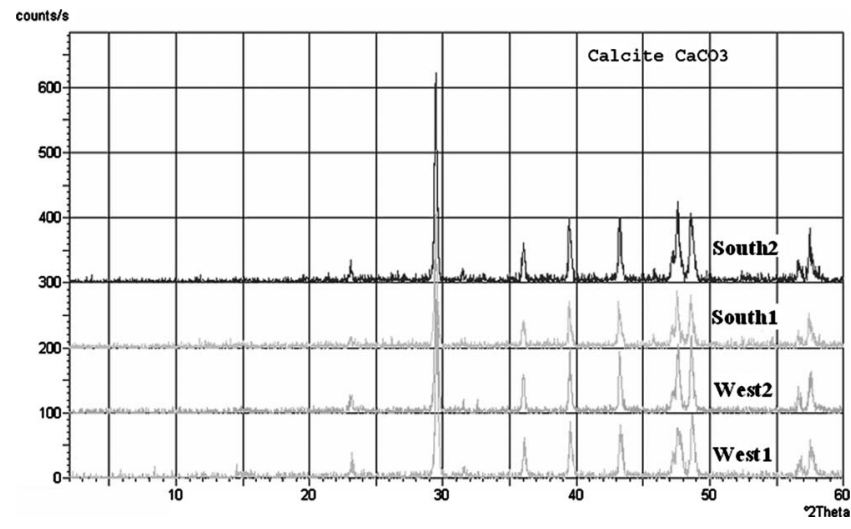

Fig. 8. XRD analyses of stone samples ( $x$-axis: XRD angle; $y$-axis: counts/s)

diffraction (XRD) (PANalytical, Almelo, The Netherlands) as seen in Fig. 8.

Microstructural analyses of stones were made by using Philips XL 30S-FEG scanning electron microscope (SEM). Fossils, $5-10 \mu \mathrm{m}$ in outer diameter, were observed on the stone samples obtained from the south section as in Fig. 9. Fossils were not observed on the samples obtained from the west section. The Schmidt Hammer and pulse velocity values of the stones obtained from west section are higher than for the stones obtained from the south section.

The compressive strength of the stones from the west section is approximately two times the compressive strength of the stones from the south section. Also the modulus of elasticity of the stones from the west section is approximately three times the modulus of elasticity of the stones from the south section. The porosity of the stones taken from the south section is at least five times the porosity of the stones taken from the west section, which causes extensive differences in strength of stone samples. This porosity difference might be because of the impurities such as the detected fossils in the stone samples of the south section, by SEM. Fossils could not be observed in the stone samples taken from the west section. By considering the bond arrangement of the west wall to be more qualified then the other walls, and the strength and fossil containment, it is highly probable that the stones of the west wall could belong to a different quarry than the stones of the other walls.

The porosity of brick masonry mortar is higher than the porosity of stone masonry mortar. The density of brick masonry mortar is lower than the density of stone masonry mortar. However, the strength of brick masonry mortar is higher than the strength of stone masonry mortar. The constructers of the struc-

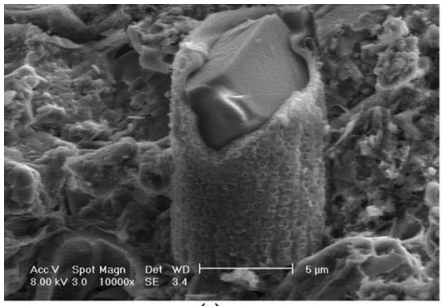

(a)

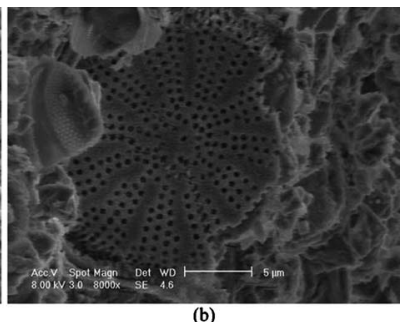

Fig. 9. SEM view of stone samples from south section: (a) fossil in stone sample south 1 ; (b) fossil in stone sample south 2 
Table 2. Homogenized Material Parameters for Stone and Brick Masonry

\begin{tabular}{lcc}
\hline Parameter & $\begin{array}{c}\text { Stone } \\
\text { masonry }\end{array}$ & $\begin{array}{c}\text { Brick } \\
\text { masonry }\end{array}$ \\
\hline Young's modulus, $E$ & $1.10 \mathrm{GPa}$ & $0.27 \mathrm{GPa}$ \\
Poisson's ratio, $v$ & 0.17 & 0.17 \\
Density & $2,482 \mathrm{~kg} / \mathrm{m}^{3}$ & $1,700 \mathrm{~kg} / \mathrm{m}^{3}$ \\
Compressive strength, $f_{c}$ & $10.77 \mathrm{MPa}$ & $4.25 \mathrm{MPa}$ \\
Tensile strength, $f_{t}$ & $1.077 \mathrm{MPa}$ & $0.425 \mathrm{MPa}$ \\
Strain at end of softening curve, $\varepsilon_{o}$, & 0.003 & 0.003 \\
when normal stress is at or very & & \\
near to zero & & \\
\hline
\end{tabular}

${ }^{\mathrm{a}}$ Source: FEA Ltd. (2002).

ture were sensible for the mortar of brick masonry which was used for the dome that is lighter but stronger than the stone masonry mortar.

\section{Structural Analyses}

A 3D finite-element model of the structure was developed using the data of measurement survey. Lusas FE software was used for developing the model. Eight node hexahedral elements and six node pentahedral elements were used in the model. The number of hexahedral elements was 3,793 and the number of pentahedral elements was 24. Pentahedral elements were used to mesh the dome. The critical parts of the structure under self-weight, seismic, and settlement loads were determined. Linear and nonlinear settlement analyses were conducted to determine the reasons for the existing cracks on the east and west walls and to investigate the critical locations of the structure under settlement load.

\section{Determination of Material Parameters for Finite-Element Model}

The masonry composite media was modeled by use of homogenization approach. Homogenization equations, which depend on mechanical properties of constituents (masonry unit and mortar), were used to determine the mechanical properties of masonry media.

The compressive strength of masonry is determined by Eq. (1) (European Committee for Standardization 1996)

$$
f_{c}=K \times f_{\mathrm{cu}}^{0.65} \times f_{\mathrm{cm}}^{0.25}
$$

where $K=$ constant; $f_{\text {cu }}=$ compressive strength of unit (stone or brick); and $f_{\mathrm{cm}}=$ compressive strength of mortar. $K$ is in the range of $0.6-0.4$ with 0.05 variations. The value of $K$ depends on the morphology of the masonry (European Committee for Standardization 1996). In this study $K$ is equal to 0.5 .

The modulus of elasticity of masonry is determined by Eq. (2) (Lourenço et al. 2001)

$$
E=\frac{t_{m}+t_{u}}{\frac{t_{m}}{E_{m}}+\frac{t_{u}}{E_{u}}} \times \rho
$$

where $t_{m}, t_{u}, E_{m}$, and $E_{u}=$ thickness of $\operatorname{mortar}\left(t_{m}=0.01 \mathrm{~m}\right)$ and unit [stone $\left(t_{\mathrm{st}}=0.25 \mathrm{~m}\right)$ or brick $\left.\left(t_{b}=0.03 \mathrm{~m}\right)\right]$, and modulus of elasticity of mortar and unit, respectively. The coefficient $\rho$ varies with the bond between mortar and unit and was taken to be 0.5 for this study (Lourenço et al. 2001).

The tensile strength of masonry can be taken as $10 \%$ of compressive strength of masonry (Koçak 1999). The Poisson's ratio of the masonry was taken as 0.17 (Koçak 1999).

The mechanical properties of the stones from the south wall and mortar at Table 1 were used to determine the stone masonry compressive strength, tensile strength, and modulus of elasticity. Also, the mechanical properties of brick and mortar in Table 1 were used for calculating the mechanical properties of brick masonry.

The density of the masonry was found by weighted average of the areas of unit and mortar and their densities. The mechanical properties and densities of stone and brick masonry are presented in Table 2. In the finite-element model, these estimated values for

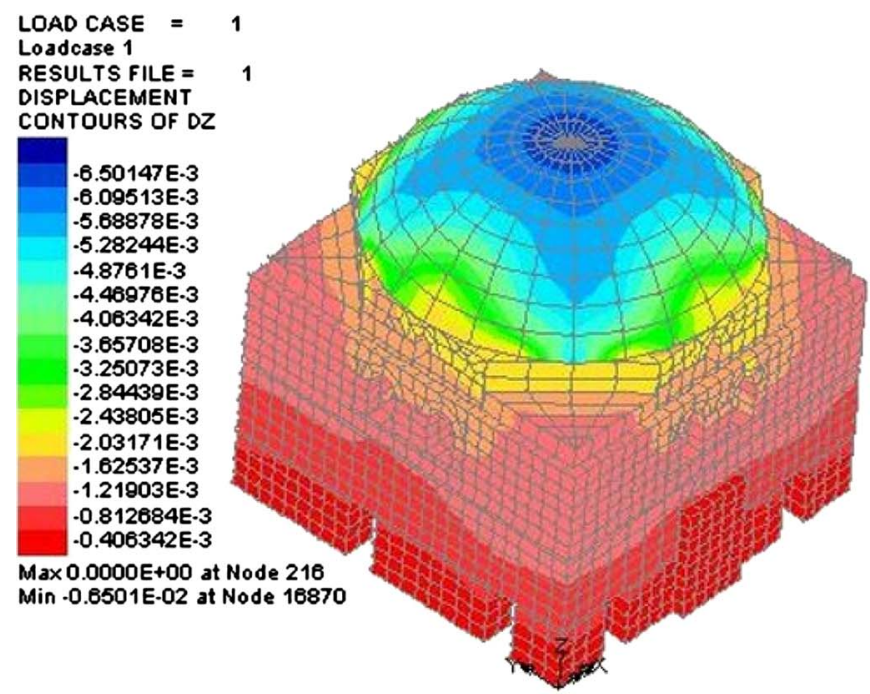

(a)

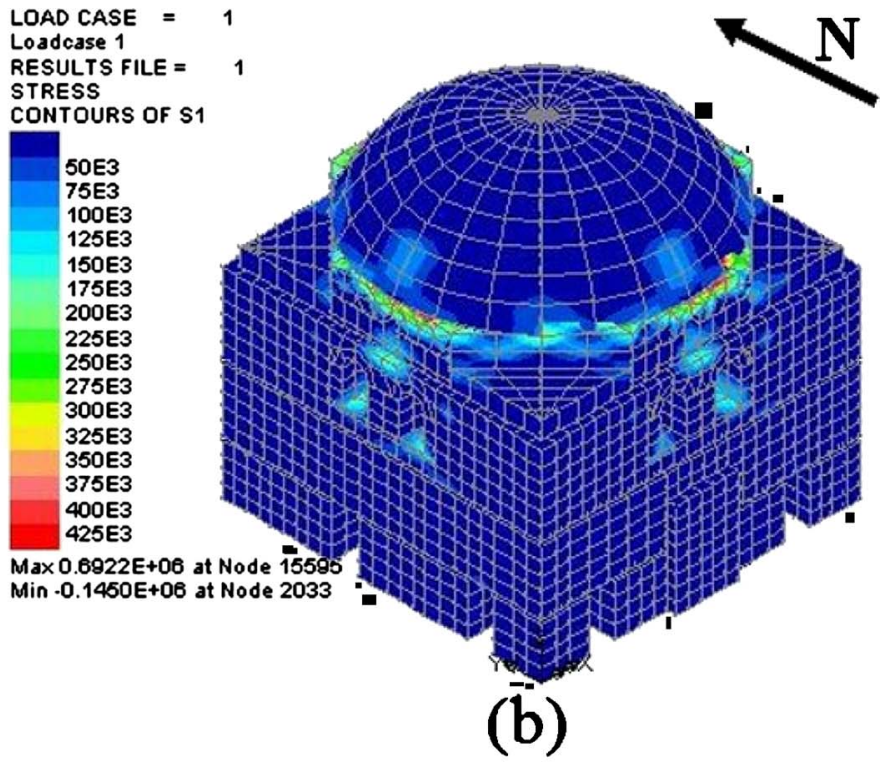

Fig. 10. Analysis results under self-weight: (a) vertical displacements [DZ (m)]; (b) first principal stresses [S1 (Pa)] 


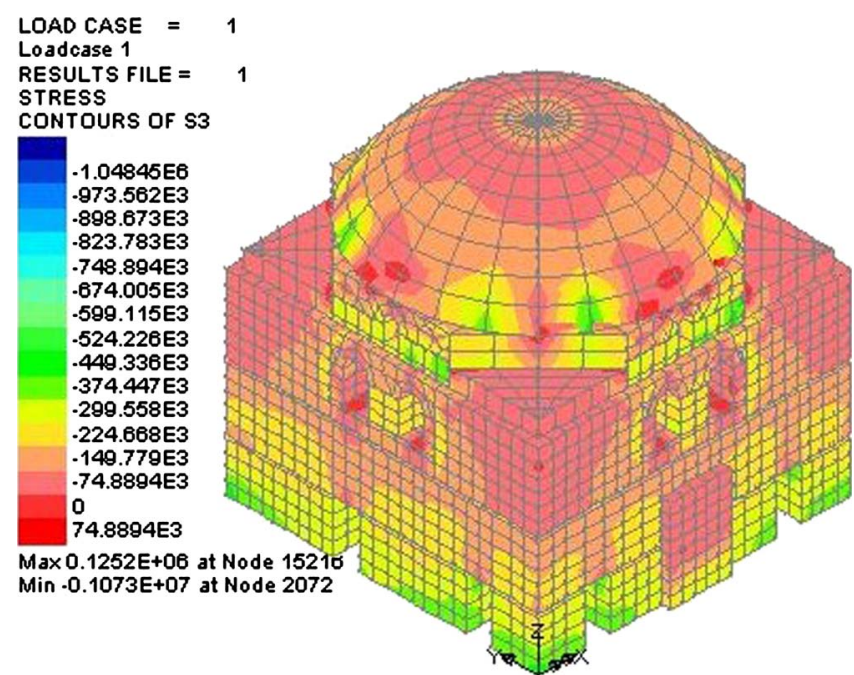

Fig. 11. Third principal stress results under self-weight $[\mathrm{S} 3(\mathrm{~Pa})]$

stone masonry were used in modeling the walls and the values estimated for brick masonry were used in modeling the dome, squinches, and the windows' arches.

\section{Self-Weight Analyses}

Linear elastic self-weight analysis of the structure was conducted in order to investigate the condition of the structure under its self-weight. Also, the relationship between stress state under selfweight and the existing cracks was investigated.

In the self-weight analyses, the vertical displacements (DZ) increases to the higher points as expected [Fig. 10(a)]. The portions of the dome resting on the corners sag more than the other portions. On the corners, the weight of the dome is transmitted to the walls by drum and squinches. On the sides, the weight of the dome is transmitted to the walls by the drum directly. The maximum absolute vertical displacement is $6 \mathrm{~mm}$, at the top of the key stone of the dome.

The highest first principal stresses (S1) are at the drum-dome connection on the drum which is stone masonry [Fig. 10(b)]. The maximum first principal stress $\mathrm{S} 1=0.69 \mathrm{MPa}$ is smaller than the tensile strength $f_{t, s m}=1.077 \mathrm{MPa}$. At the bottom corners of the second level windows, relatively high tensional stresses occur

Table 3. Vibration Modes, Corresponding Frequencies, and Mass Participation Factors

\begin{tabular}{|c|c|c|c|c|}
\hline \multirow[b]{2}{*}{ Mode } & \multirow{2}{*}{$\begin{array}{l}\text { Frequency } \\
\qquad(\mathrm{Hz})\end{array}$} & \multicolumn{3}{|c|}{$\begin{array}{l}\text { Mass participation factor } \\
(\%)\end{array}$} \\
\hline & & $X$ & $Y$ & $Z$ \\
\hline 1 & 4.76 & 37.08 & 30.16 & 0.00 \\
\hline 2 & 4.77 & 31.42 & 35.27 & 0.00 \\
\hline 3 & 5.67 & 0.00 & 0.20 & 0.00 \\
\hline 4 & 6.91 & 0.01 & 0.00 & 0.00 \\
\hline 5 & 7.54 & 0.01 & 0.01 & 16.12 \\
\hline 6 & 7.85 & 0.14 & 0.00 & 0.58 \\
\hline 7 & 8.35 & 0.23 & 1.31 & 0.00 \\
\hline 8 & 8.50 & 1.94 & 0.25 & 0.00 \\
\hline 9 & 9.06 & 0.04 & 0.31 & 0.00 \\
\hline 10 & 9.32 & 10.45 & 0.01 & 0.00 \\
\hline
\end{tabular}

(a)

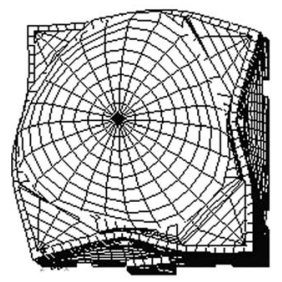

(b)

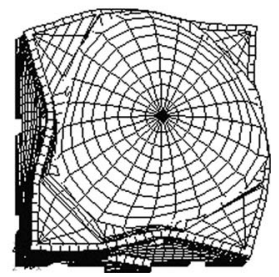

Fig. 12. (a) First mode shape; (b) second mode shape

[Fig. 10(b)]. These stress concentrations coincide with the crack's route in east and west walls. The $\mathrm{S} 1$ stresses are lower than the tensile strength of brick masonry $f_{t, b m}=0.425 \mathrm{MPa}$ where brick masonry is used (dome, windows' arches, and squinches).

The minimum of the third principal stress $(\mathrm{S} 3=-1 \mathrm{MPa})$ is not higher than the compressive strength of stone masonry $\left(f_{c, s m}\right.$ $=10.8 \mathrm{MPa})$ and brick masonry $\left(f_{c, b m}=4.3 \mathrm{MPa}\right)$ (Fig. 11). It can be concluded that self-weight does not cause the cracks individually but might support their formation with other load conditions.

\section{Modal Analyses}

The vibration modes, corresponding frequencies and mass participation factors are presented in Table 3 . The frequencies of the first two modes are very close to each other because the structure shows a partial symmetry. The mode shapes of the first and second modes are given in Fig. 12. The mode shapes of the first and second modes also show a great resemblance as a result of the partial symmetry.

\section{Response Spectrum Analyses}

The response spectrum analysis was conducted according to specification of Ministry of Public Works and Settlement, Government of Republic of Turkey (1998). Ten modes having the lowest frequencies were included in the spectrum analyses. Selfweight was not considered in the spectrum analyses as a load.

The acceleration response spectrum is defined as

$$
A_{c}=A(T) \times 9.81
$$

where $A_{c}$ and $A(T)=$ respectively, spectral acceleration and spectral acceleration coefficient which is normalized by acceleration of gravity, $g$

$$
A(T)=A_{o} \times I \times S(T)
$$

The $A_{o}, I$, and $S(T)=$ effective ground acceleration coefficient, building importance factor, and spectrum coefficient, respectively.

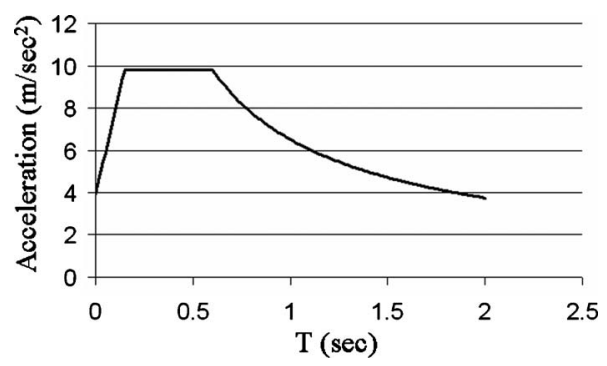

Fig. 13. Acceleration response spectrum 


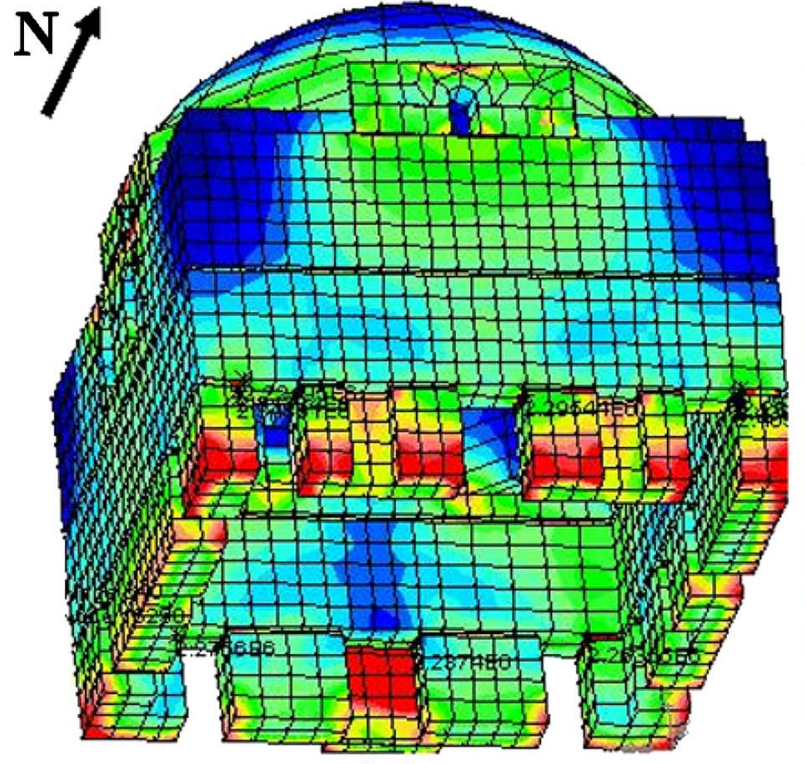

(a)
SPECTRAL RESPONSE

CQC Combination

Chosen Spectrum Dataset 1

STRESS

CONTOURS OF S1

$61.7 \mathrm{E3}$

$129.4 \mathrm{E3}$

$197.1 \mathrm{E3}$

$264.8 \mathrm{E3}$

332.5 E3

$400.2 \mathrm{E3}$

$467.8 \mathrm{E3}$

535.5 E3

$603.2 \mathrm{E3}$

$670.9 \mathrm{E3}$

$738.6 \mathrm{E3}$

806.3 E3

873.9 E3

$941.6 \mathrm{E3}$

$1009 \mathrm{E3}$

$1077 \mathrm{E3}$

Max $2465 E+03$ at Node 640

Min 27.89 E+03 at Node 1629

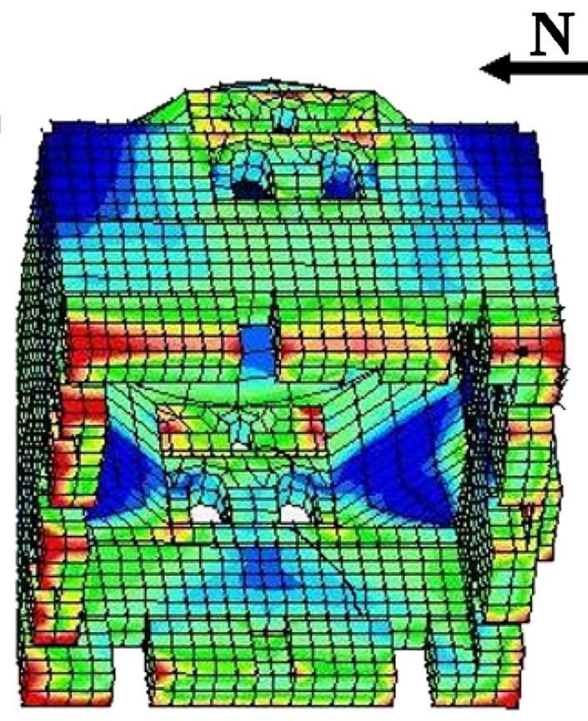

(b)

Fig. 14. $\mathrm{S} 1(\mathrm{~Pa})$ contours due to spectral excitation in $X$ (east) direction: (a) east and north elevations; (b) east section (the existing crack is plotted on the figure for comparison with stress contours)

The spectrum coefficient $S(T)$ can be determined as

$$
\begin{gathered}
S(T)=1+1.5 T / T_{A} \quad\left(0 \leqslant T \leqslant T_{A}\right) \\
S(T)=2.5 \quad\left(T_{A}<T \leqslant T_{B}\right) \\
S(T)=2.5\left(T_{B} / T\right)^{0.8}\left(T>T_{B}\right)
\end{gathered}
$$

where $T, T_{A}$, and $T_{B}=$ natural period of the structure and spectrum characteristic periods depending on local soil conditions, respectively.

Due to the information in the geological reports by Alkan (1994) and Ispir (2000), the spectrum characteristic periods were determined to be $T_{A}=0.15 \mathrm{~s}$ and $T_{B}=0.6 \mathrm{~s}$ (Ministry of Public Works and Settlement, Government of Republic of Turkey 1998).
Effective ground acceleration coefficient was taken as $A_{0}$ $=0.4$ as the structure is in the first-order seismic zone. The building importance factor was taken as $I=1$ (Ministry of Public Works and Settlement, Government of Republic of Turkey 1998). The acceleration response spectrum is defined using Eqs. (3), (4), and $(5 a)-(5 c)$ and presented in Fig. 13. The response spectrum analyses were performed for the $X$ and $Y$ directions of the model.

For the excitation in the $X$ (east) direction, the first principle stress $(\mathrm{S} 1=2.5 \mathrm{MPa})$ exceeds the tensile strength of stone masonry $\left(f_{t, s m}=1.08 \mathrm{MPa}\right)$ at the lower level lintel at the north and south sections where the sections of the walls decrease considerably [Fig. 14(a)]. The tensile stresses are critical at the drumdome connections and at the foundation, especially at the north where the tensile stresses exceed the tensile strength [Fig. 14(a)].

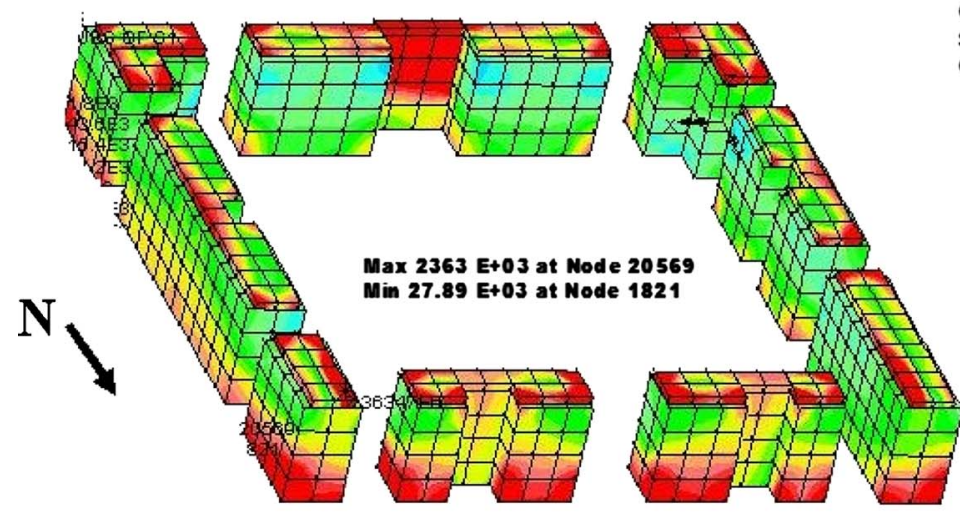

(a)

\begin{tabular}{l} 
SPECTRAL RESPONSE \\
CQC Combination \\
Chosen Spectrum Dataset 1 \\
STRESS \\
CONTOURS OF S1 \\
\hline $61.7 \mathrm{E3}$ \\
$129.4 \mathrm{E3}$ \\
$197.1 \mathrm{E3}$ \\
$264.8 \mathrm{E3}$ \\
$332.5 \mathrm{E3}$ \\
$400.2 \mathrm{E3}$ \\
$467.8 \mathrm{E3}$ \\
$535.5 \mathrm{E3}$ \\
$603.2 \mathrm{E3}$ \\
$670.9 \mathrm{E3}$ \\
$738.6 \mathrm{E3}$ \\
$806.3 \mathrm{E3}$ \\
$873.9 \mathrm{E3}$ \\
$944.6 \mathrm{E3}$ \\
$1009 \mathrm{E3}$ \\
$1077 \mathrm{E3}$
\end{tabular}

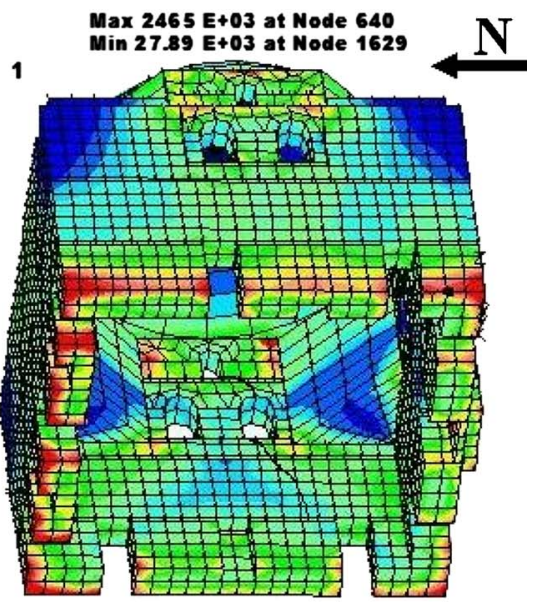

(b)

Fig. 15. $\mathrm{S} 1(\mathrm{~Pa})$ contours due to spectral excitation in $Y$ (north) direction: (a) east and north elevations; (b) east section (the existing crack is plotted on the figure for comparison with stress contours) 


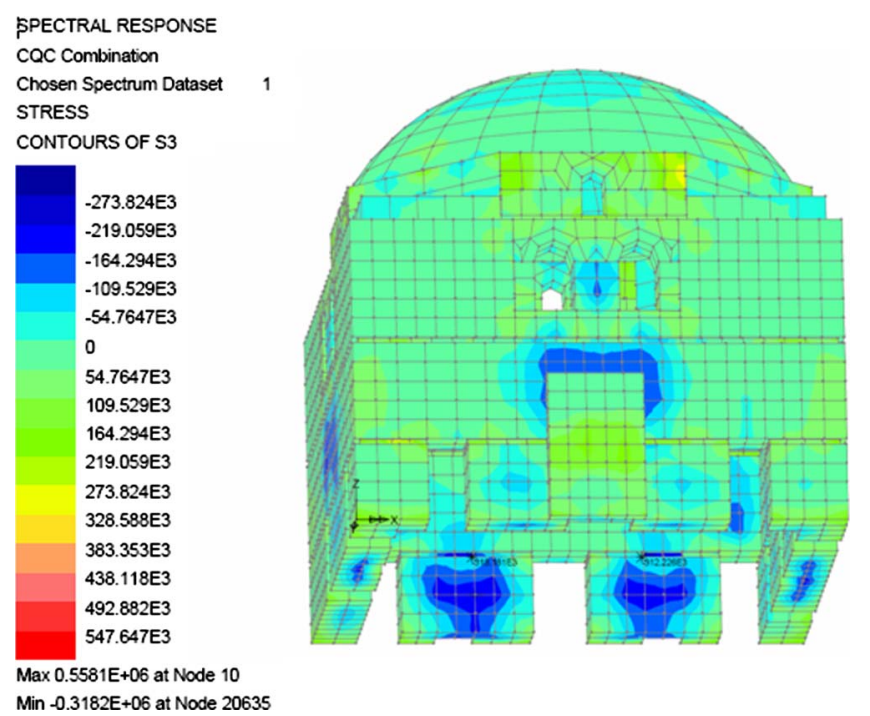

Fig. 16. $\mathrm{S} 3(\mathrm{~Pa})$ contours due to spectral excitation in $Y$ (north) direction

The S1 does not exceed tensile strength of brick masonry $\left(f_{t, b m}\right.$ $=0.43 \mathrm{MPa}$ ) at dome, squinches, and windows' arches which are brick masonry.

The $\mathrm{S} 1$ is lower than the tensile strength at crack locations [Fig. 14(b)]. The absolute value of the third principle stress (S3) is lower than the compressive strength for both stone masonry $\left(f_{c, s m}=10.8 \mathrm{MPa}\right)$ and brick masonry $\left(f_{c, b m}=4.3 \mathrm{MPa}\right)$.

For the excitation in the $Y$ (north) direction, the first principal stress $(\mathrm{S} 1=2.4 \mathrm{MPa})$ exceeds the tensile strength of stone masonry $\left(f_{t, s m}=1.08 \mathrm{MPa}\right)$ at the lower level lintel at the east section [Fig. 15(a)]. North and south lintel locations have high tensile stresses which are critical. The foundation has tensile stresses

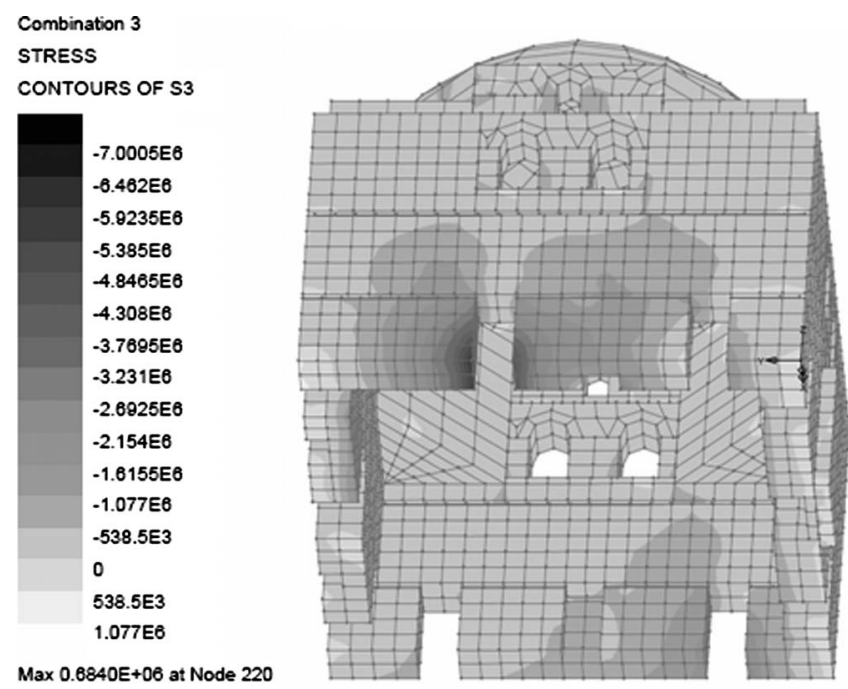

Min $-0.7034 E+07$ at Node 690

Fig. 18. $\mathrm{S} 3(\mathrm{~Pa})$ contours for linear elastic settlement+self-weight

larger than the strength especially at the north while the drum also has large tensile stresses [Fig. 15(b)]. In the east and west sections, the tensile stresses are lower than the strength at the crack locations [Fig. 15(b)]. The S1 does not exceed tensile strength of brick masonry $\left(f_{t, b m}=0.43 \mathrm{MPa}\right)$ at dome, squinches, and windows' arches which are brick masonry.

The $\mathrm{S} 1$ is lower than the tensile strength at crack locations [Fig. 15(b)]. The minimum of the third principal stress $(\mathrm{S} 3=$ $-0.32 \mathrm{MPa}$ ) is lower than the compressive strength for both stone masonry $\left(f_{c, s m}=10.8 \mathrm{MPa}\right)$ and brick masonry $\left(f_{c, b m}=4.3 \mathrm{MPa}\right)$ as seen in Fig. 16.

In general, the empty places of the lintels challenge the struc-

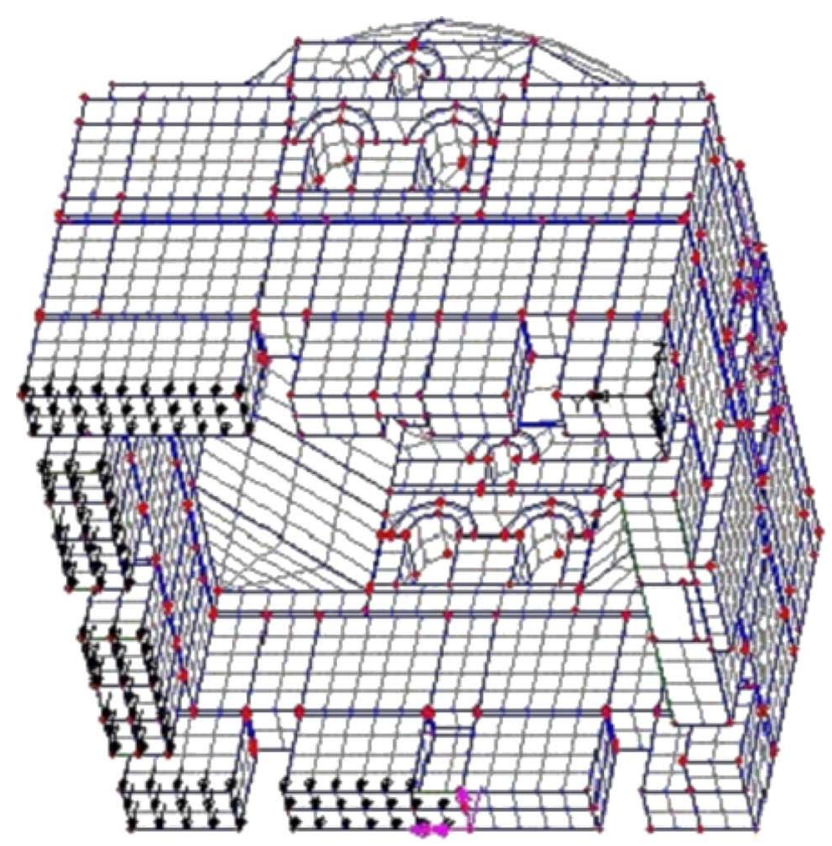

(a)

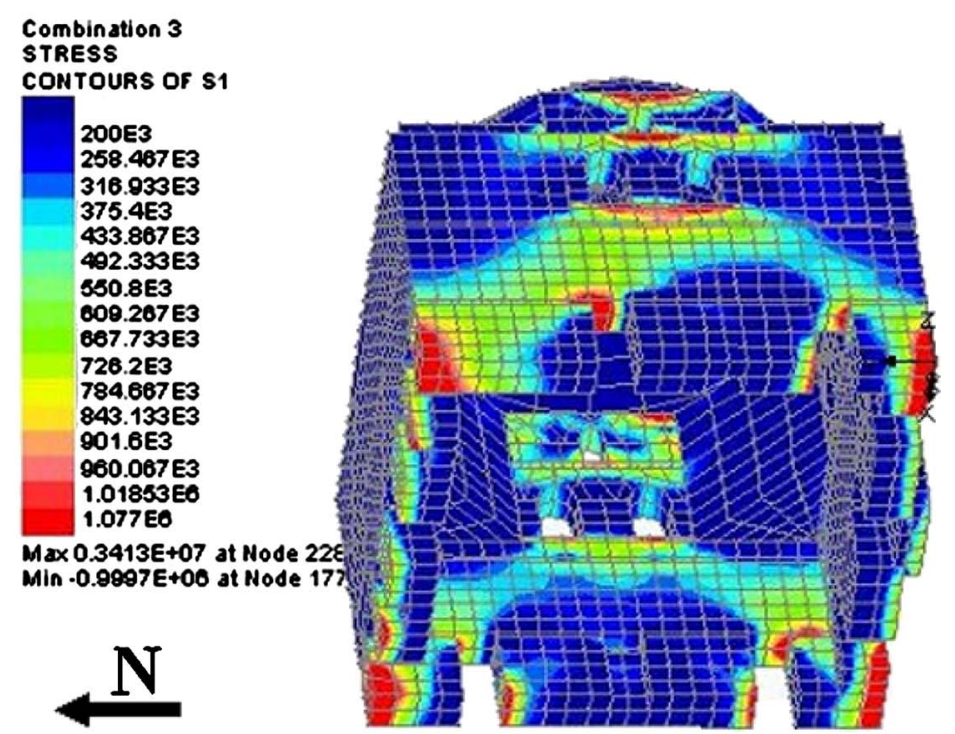

(b)

Fig. 17. (a) Settlement loading; (b) S1 (Pa) contours for linear elastic settlement+self-weight 


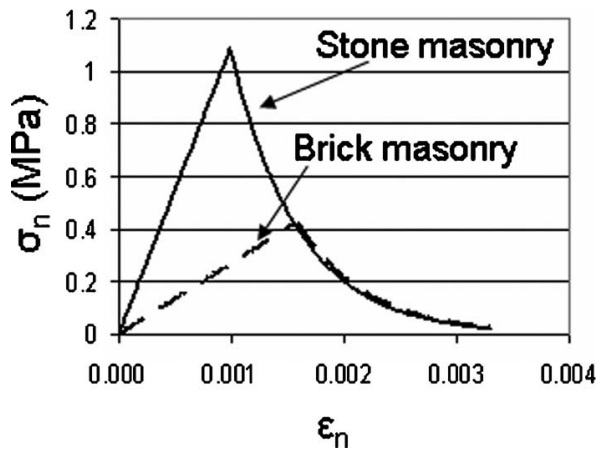

Fig. 19. Stress-strain curves normal to crack plane for stone and brick masonry ( $\varepsilon n$ : strain normal to crack plane; $\sigma n$ : stress normal to crack plane) (FEA Ltd. 2002)

ture in a seismic excitation. The drum-dome connections are also critical for seismic excitations. The tensile stresses are below the tensile strength at crack locations.

\section{Linear Elastic Settlement Analyses}

The long-term observations showed that there was a settlement toward the north direction. In linear elastic settlement analyses, the settlement was given by linear increase that starts with zero on the east and west walls' foundations and reaches maximum at the north foundation [Fig. 17(a)]. The results are given here for dead load plus settlement combination. The maximum S1=3.4 MPa is at the lintel places at the northwest corner. Tensile stresses are higher than tensile strength of stone masonry $\left(f_{t, s m}=1.08 \mathrm{MPa}\right)$ at northwest foundation, the drum-dome connections on the east and west. The S1 exceed tensile strength of brick masonry $\left(f_{t, b m}\right.$ $=0.43 \mathrm{MPa}$ ) at first and second level windows' arches which are brick masonry. The high tensile stresses coincide with the cracks at the east and west walls of the structure [Fig. 17(b)].

The minimum of $\mathrm{S} 3=-7 \mathrm{MPa}$ at the west foundation is smaller than compressive strength of stone masonry $\left(f_{c, s m}\right.$ $=10.8 \mathrm{MPa}$ ) (Fig. 18). The S3 is smaller than compressive strength of brick masonry $\left(f_{c, b m}=4.3 \mathrm{MPa}\right)$ at dome, windows' arches, and squinches.

\section{Nonlinear Settlement Analyses}

The aim of the nonlinear analyses is to understand the causes of the existing cracks on the structure and to investigate the vital parts of the structure under settlement loading. A nonlinear material model of LUSAS FE software was used which simulates the tensile cracking while crushing failure because of compression is
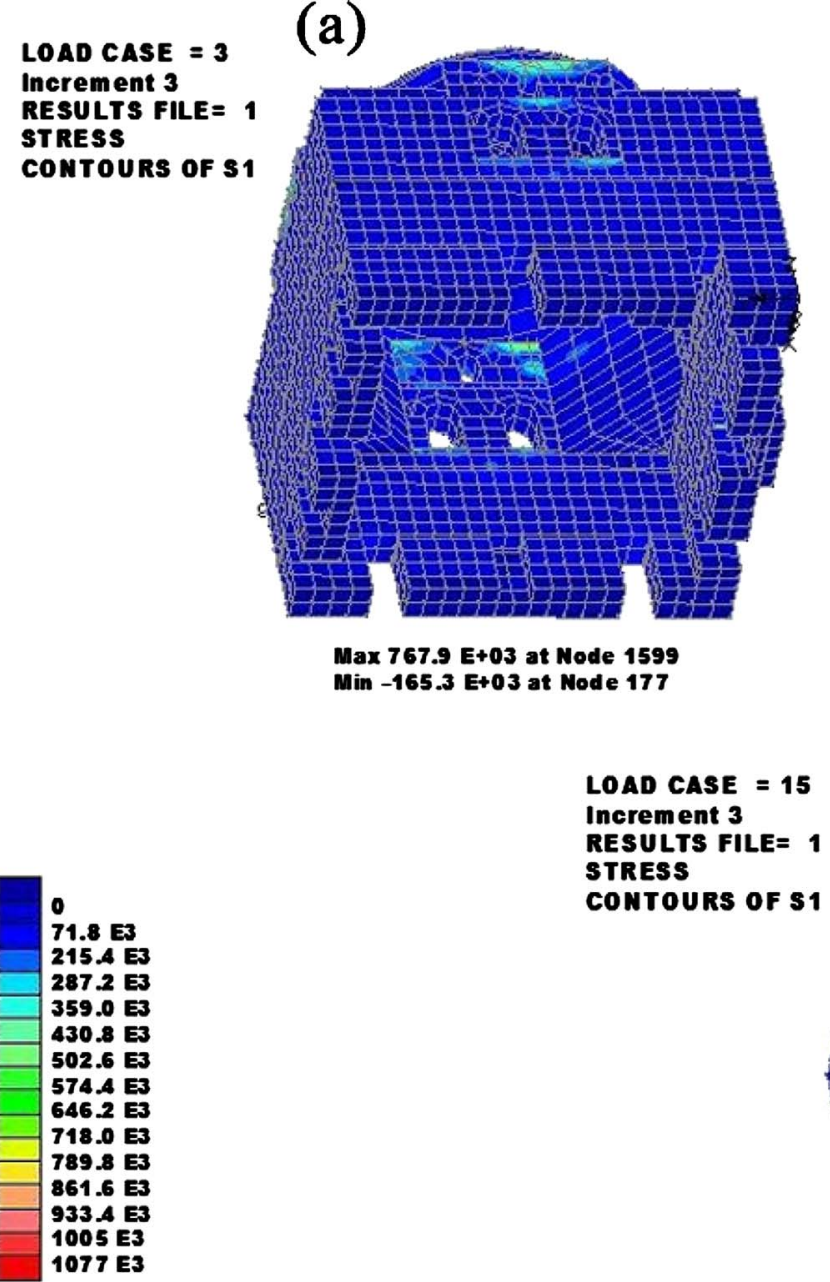

LOAD CASE $=15$ Increment 3 RESULTS FILE= 1 STRESS CONTOURS OF 1

(c)
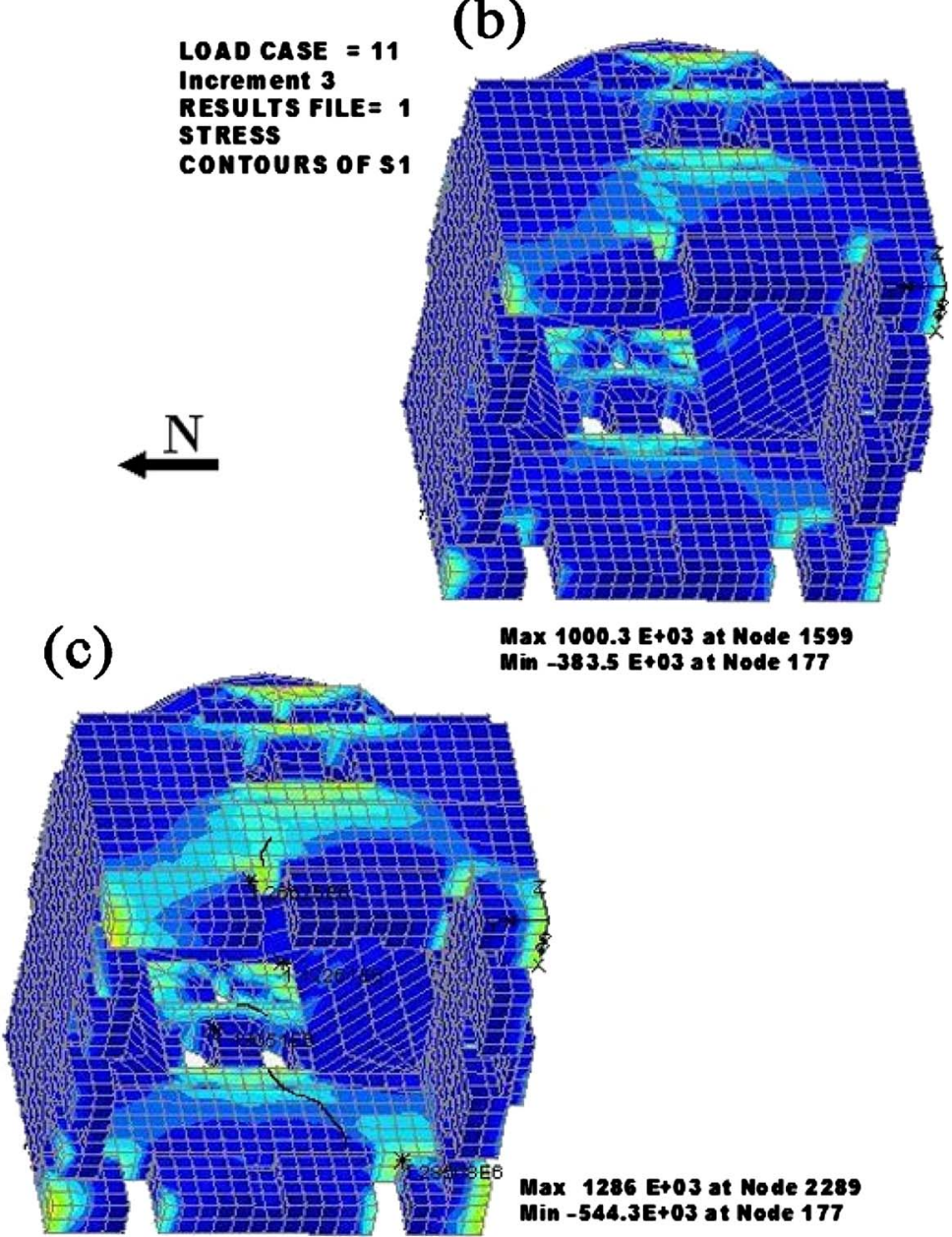

Fig. 20. The first principal stress $[\mathrm{S} 1(\mathrm{~Pa})]$ results for the nonlinear settlement analyses, east section and west elevation: (a) after 3rd increment; (b) after 11th increment; and (c) after 15th increment with cracks (the existing cracks are plotted on the figure for comparison with stress contours) 


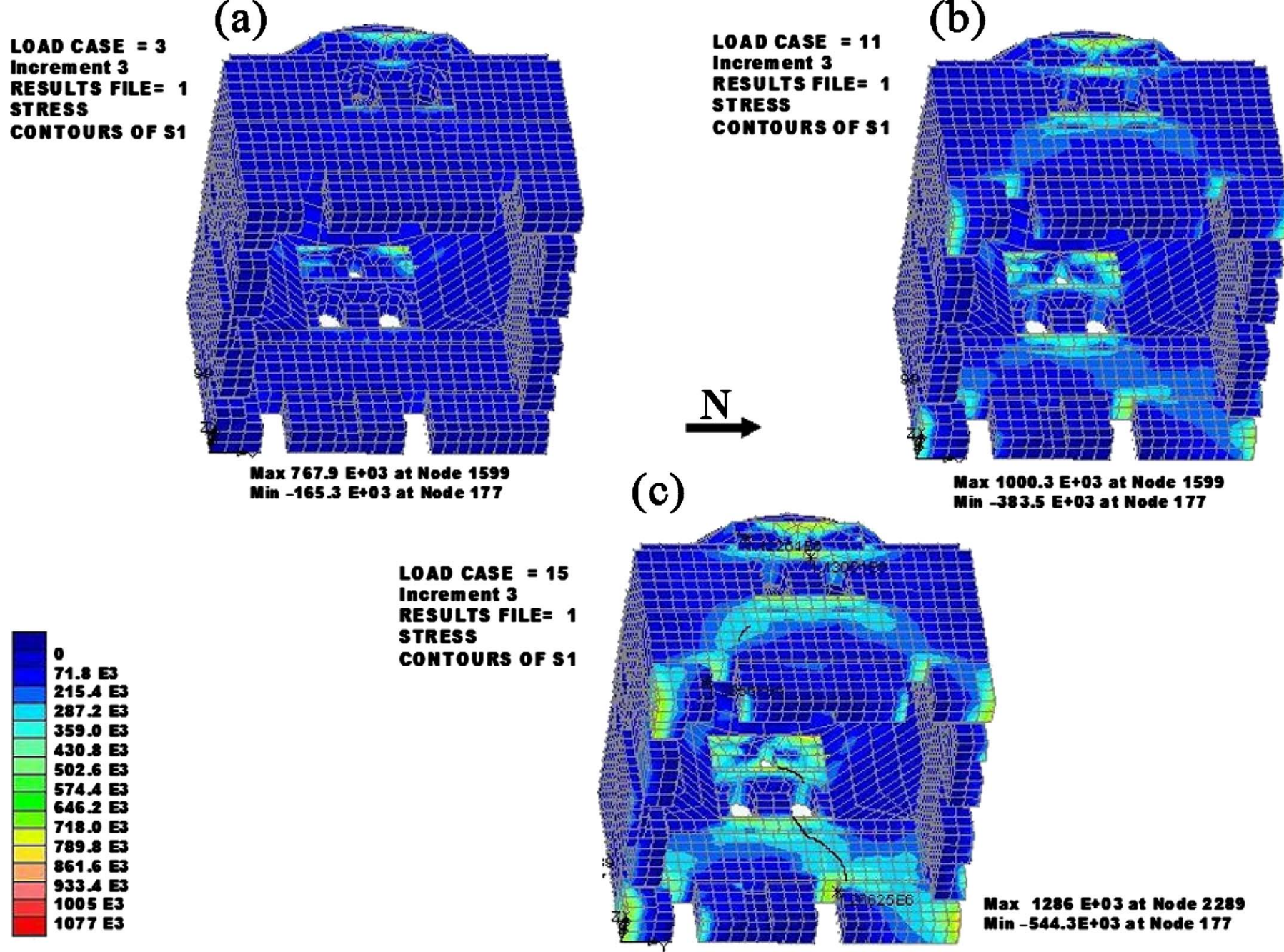

Fig. 21. The first principal stress $(\mathrm{Pa})$ results for the nonlinear settlement analyses, west section and east elevation: (a) after the third increment; (b) after 11th increment; and (c) after 15th increment with cracks (the existing cracks are plotted on the figure for comparison with stress contours)

neglected. The model assumes that at any one point there are 21 cracking directions for the 3D case (FEA Ltd. 2002).

Three crack directions are active at any one time and are defined by the closest directions to the principal strain directions. Total principal strains are used to define the cracking directions rather than stresses because strains grow with the increasing fracture but stresses diminish to zero and do not provide a good measure of previous fracture directions (FEA Ltd. 2002). In tensile loading an exponential softening curve of stress-strain relationship is defined normal to crack plane for stone masonry and brick masonry (Fig. 19).

The strain at the end of softening curve is assumed to be 0.003 , equal to the value for concrete. In order to check the sensitivity of the results to this assumption, the analyses were repeated for 0.002 and 0.004 and no significant change in results was observed.

The settlement load was applied starting with zero at east and west foundations, increasing toward the north foundation, as in Fig. 17(a). The nonlinear analysis was performed by acting the self-weight plus the settlement load.

The first principal stress (S1) results for the nonlinear settlement analyses are presented in Fig. 20 for east section and west elevation. Initially, the stress concentrations start at the drum and second level windows on the east section and west elevation
[Fig. 20(a)]. The stress concentrations at the drum and second level window unite with the concentrations at the first level window and the empty lintel places [Figs. 20(b and c)]. The stress concentration captures the cracks observed on the structure [Fig. 20(c)]. The maximum $\mathrm{S} 1=1.3 \mathrm{MPa}$ is greater than tensile strength of stone masonry $\left(f_{t, s m}=1.08 \mathrm{MPa}\right)$. The $\mathrm{S} 1$ is greater than tensile strength of brick masonry $\left(f_{t, b m}=0.43 \mathrm{MPa}\right)$ at the first-second-third windows' arches where the cracks are located.

For the west section and east elevation, first principal stress (S1) contours for the nonlinear settlement analyses are presented in Fig. 21. The stresses start to concentrate at the west and east drum and second level windows. These stress concentrations unite with the ones at the first level windows and lintel places (Fig. 21). The routes of the existing cracks observed are captured by stress concentrations on the west section and east elevation very well (Fig. 21). The maximum $\mathrm{S} 1=1.3 \mathrm{MPa}$ is greater than tensile strength of stone masonry $\left(f_{t, s m}=1.08 \mathrm{MPa}\right)$. The $\mathrm{S} 1$ is greater than tensile strength of brick masonry $\left(f_{t, b m}=0.43 \mathrm{MPa}\right)$ at the first-second-third windows' arches where the cracks are located.

In Figs. 22(a and b), the first principal stress (S1) contour sections of the west and east walls are presented. The existing 

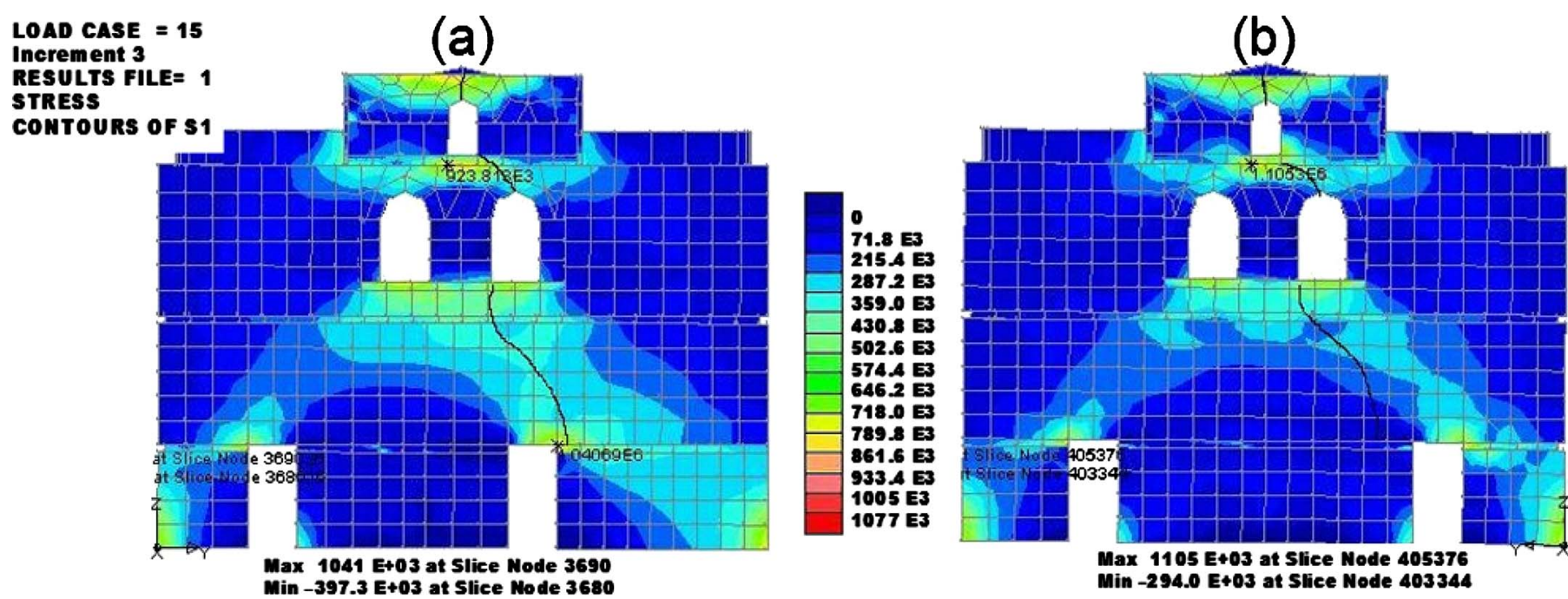

Fig. 22. The first principal stress (Pa) results for the nonlinear settlement analyses: (a) west wall; (b) east wall (the existing cracks are plotted on the figure for comparison with stress contours)

cracks observed on the structure are also shown. The locations where the stress concentrations are obtained match with the existing cracks' locations.

The minimum of $\mathrm{S} 3=-4.6 \mathrm{MPa}$ at stone masonry is smaller than compressive strength of stone masonry $\left(f_{c, s m}=10.8 \mathrm{MPa}\right)$ (Fig. 23). The S3 is smaller than compressive strength of brick masonry $\left(f_{c, b m}=4.3 \mathrm{MPa}\right)$ at dome, windows' arches, and squinches (Fig. 23).

The empty lintel locations form weak zones and make the structure vulnerable. The window openings also are on the route of the cracks and excessive stresses. The section of the drum is smaller than the walls. With the heavy dome resting on it and the drum windows, the drums of especially east and west are critical. Compressive stresses are lower than the strength as expected. This validates the assumption of compatibility of the tensile cracking failure of masonry and not including the compressive crushing.

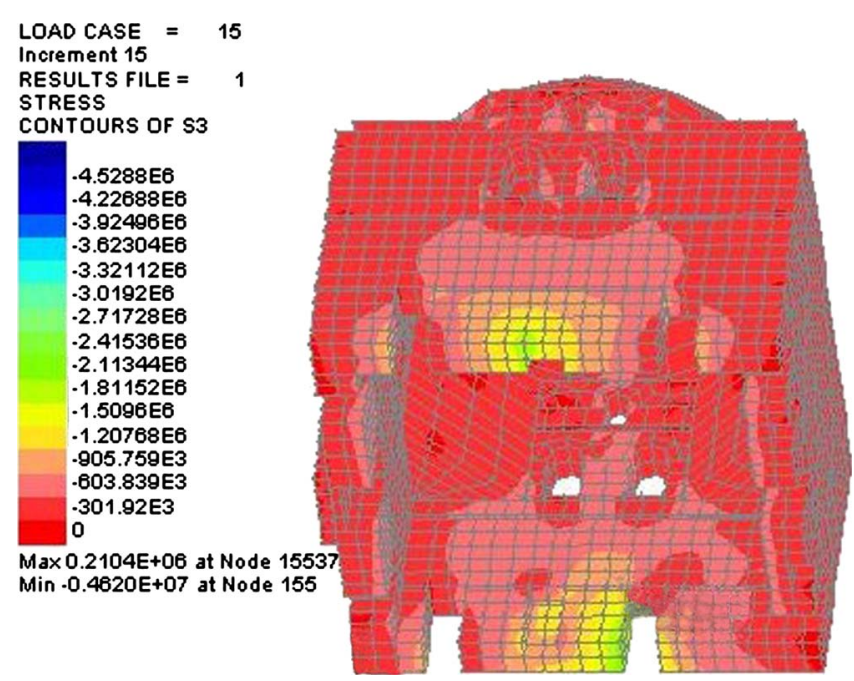

Fig. 23. S3 (Pa) contours for nonlinear settlement analyses

\section{Conclusions}

An interdisciplinary study was conducted for assessment of a historical masonry structure, Urla Kamanli Mosque in Izmir, Turkey. The comparative methods of architectural elements in light of art history show that the structure was constructed during early 14th century to mid-15th century. A measurement survey revealed that the structure has a square plan of $10 \mathrm{~m} \times 10 \mathrm{~m}$ with a wall thickness of $110 \mathrm{~cm}$ and the height is $12.66 \mathrm{~m}$. The measurement survey provided the detailed data used for developing the $3 \mathrm{D}$ finite-element model of the structure.

Visual inspection showed that there are extensive cracks on the east and west walls, uniting at the key stone of the dome. The wooden lintels which should surround the structure at two levels did not exist. The empty places of the lintels decrease the wall cross sections. Long-term settlement observations revealed that there was a settlement toward north direction of the structure.

Material degradation inside the structure, especially at the first $1 \mathrm{~m}$ from the ground, was observed. Long-term moisture measurements showed that the moisture at the first $1 \mathrm{~m}$ from ground was higher than the moisture at $2 \mathrm{~m}$ from ground which causes material degradation.

Nondestructive and destructive tests were conducted on stone, brick, and mortar of the structure and mechanical properties were measured. The stones of the west wall have higher modulus of elasticity and compressive strength with respect to the stones of the south wall. The porosity of the stones obtained from west wall was lower than porosity of the stones obtained from the south wall. The high porosity of the south wall stone is due to the impurities such as fossils which were not observed in the stones obtained from the west wall.

The brick masonry mortar used at the dome has lower density and higher strength with respect to stone masonry mortar which was used at the walls. This shows the wisdom of the constructors of the structure centuries before.

A 3D finite-element model of the structure was developed using the data of measurement survey and material tests. The critical parts of the structure under self-weight, seismic, and settlement loads were determined. The reason for the existing 
cracks of the structure was investigated using the model.

The finite-element analyses revealed that:

1. The critical locations of the structure under self-weight are drum-dome connections and second level windows which are on the existing cracks' route. The self-weight does not cause the cracks individually, but might support cracks' formation in combination with other loads.

2. Due to the partial symmetry of the structure, the frequencies of the first and second modes are close to each other while the mode shapes of the first and second modes also show a great resemblance.

3. Seismic analyses were done using response spectrum method. The lower level empty lintel places and drum-dome connections have high stress levels. The stresses are lower than the strength at the existing cracks' location.

4. The locations of the stress concentrations obtained from linear elastic and nonlinear settlement analyses match with the existing cracks' locations.

5. In general, the empty lintel places decrease the wall cross sections, resulting in stress concentrations. The second-level windows, drum and drum-dome connections are critical for the performance of structure.

The interdisciplinary aspect of the study showed that assessment of a historical structure can be done by collaboration and interaction of different disciplines.

\section{Acknowledgments}

We would like to thank The Scientific and Technical Research Council of Turkey (TUBITAK) for funding the project (Grant No. ICTAG I-591). Also we would like to thank the Department of Architectural Restoration of Izmir Institute of Technology for their collaboration and providing mechanical properties of mortar. We would like to thank the Materials Research Center of Izmir Institute of Technology for SEM imaging and XRD analyses.

\section{References}

Alkan, M. (1994). "Geological report of parcel 6 in town of Urla, city of Izmir." Rep. Prepared for Urla Municipality Archives, Urla Municipality, Izmir, Turkey.

Andreu, A., Gil, L., and Roca, P. (2007). "Computational analysis of masonry structures with a funicular model." J. Eng. Mech., 133(4), 473-480.

Berto, L., Saetta, A., Scotta, R., and Vitaliani, R. (2002). "An orthotropic damage model for masonry structures." Int. J. Numer. Methods Eng., 55, 127-157.

Binda, L., Saisi, A., and Tiraboschi, C. (2000). "Investigation procedures for the diagnosis of historic masonries." Constr. Build. Mater., 14(4), 199-233.

Çakmak, A. S., Davidson, R., Mullen, C. L., and Erdik, M. (1993). "Dynamic analysis and earthquake response of Hagia Sophia." Proc., Seminar on Protection of Architectural Heritage against Earthquake, Ministry of Public Works and Settlement of Turkish Republic, An- kara, Turkey, 19-37.

Erim, F. (1995). "Turkish era structures in Urla-1.” B.Sc. thesis, Ege Univ., Izmir, Turkey.

Ersoy, U. (1990). "Diagnosis, assessment and emergency interventions for the historic masonry structures." Proc., Structural Conservation of Stone Masonry, Int. Technical Conf. in Athens, Greece, ICCROM Publication, Rome, 13-19.

European Committee for Standardization. (1996). Eurocode 6: Design of masonry structures, CEN, Brussels, Belgium.

FEA Ltd. (2002). LUSAS theory manual 1, Surrey, U.K.

Giambanco, G., Rizzo, S., and Spallino, R. (2001). "Numerical analysis of masonry structures via interface models." Comput. Methods Appl. Mech. Eng., 190, 6493-6511.

Giordano, A., Mele, E., and Luca, A. (2002). "Modeling of historical masonry structures: Comparison of different approaches through a case study." Eng. Struct., 24, 1057-1069.

Heyman, J. (1982). The masonry arch, Ellis Horwood Limited, Chichester, U.K.

International Society for Rock Mechanics (ISRM). (1981). "Rock characterization, testing and monitoring: ISRM suggested methods.” E. T. Brown, ed., Pergamon, Oxford, U.K.

Ispir, N. (2000). "Geological report of parcel 24 in town of Urla, city of Izmir." Rep. Prepared for Urla Municipality Archives, Urla Municipality, Izmir, Turkey.

Koçak, A. (1999). "The linear and non-linear analysis of the historical buildings under static and dynamic loading: The study of Küçük Ayasofya Mosque.” Ph.D. thesis, Institute of Science, Yıldız Technical Univ., İstanbul, Turkey.

Lourenço, P. B. (1996). Computational strategies for masonry structures, Delft University Press, Delft, The Netherlands.

Lourenço, P. B., Vasconcelos, G., and Ramos, L. (2001). "Assessment of the stability conditions of a Cistercian Cloister." Proc., 2nd Int. Congress on Studies in Ancient Structures, Istanbul, Turkey, Y1ld1z Technical Univ., 669-678.

Ministry of Public Works and Settlement, Government of Republic of Turkey. (1998). Specification for structures to be built in disaster areas, Ankara, Turkey.

Mistler, M., Butenweg, C., and Meskouris, K. (2006). "Modeling methods of historic masonry buildings under seismic excitation." J. Seismol., 10, 497-510.

Paret, T. F., Freeman, S. A., Searer, G. R., Hachem, M., and Gilmartin, U. M. (2008). "Using traditional and innovative approaches in the seismic evaluation and strengthening of a historic unreinforced masonry synagogue.” Eng. Struct., 30, 2114-2126.

RILEM Commission 25 PEM. (1980). "Tests defining the structure." Mater. Constr., 13(75), 175-253.

Roca, P. (2001). "Analysis of gothic structure.” Proc., 2nd Int. Congress on Studies in Ancient Structures, Istanbul, Turkey, Yıldız Technical Univ., 291-300.

Schueremans, L., Balen, K. V., Brosens, K., Gemert, D. V., and Smars, P. (2007). "The Church of Saint James at Leuven: Structural assessment and consolidation measures." Int. J. Architectural Heritage., 1, 82107.

Sofronie, R. A., Popa, G., Nappi, A., and Facchin, G. (2001). "Dynamic behavior of church steeples." Proc., 2nd Int. Conf. Studies in Ancient Structures, Istanbul, Turkey, Y1ld1z Technical Univ., 399-410. 